MATRIMONIO

INVERTEBRADO

INVERTEBRATE MARRIAGE

José Gabriel Martínez de Aguirre Aldaz Ediciones Rialp, España, 2012, 128 págs.

\title{
DATOS DEL AUTOR
}

Es licenciado en Derecho por la Universidad de Castilla-La Mancha, y Doctor en Derecho Canónico por la Universidad de la Santa Cruz, en Roma.

\section{CONTENIDO}

El matrimonio ha sufrido una de las transformaciones más grandes de la historia, varios autores lo han definido como un proceso de descomposición absoluta del modelo clásico o de agonía de la familia institucionalizada; esta importante institución ha ido perdiendo su importancia a través del tiempo y la ley ha ido reformándose por los cambios sociales. Esto ha repercutido gravemente en la familia y el matrimonio. José Gabriel Martínez de Aguirre realiza un exhaustivo análisis sobre la necesidad de volver a los fines y a las características esenciales que deben componer el matrimonio, basadas en la naturaleza humana.

\section{Propiedades esenciales del matrimonio}

Unidad, indisolubilidad, complementariedad sexual orientada a la procreación son propiedades y elementos esenciales irrenunciables de la institución matrimonial.

El matrimonio ha existido siempre debido a la naturaleza humana. Entre las razones de ese carácter natural del matrimonio, encontramos: 
el instinto de conservación como medio de perpetuación de la especie, la búsqueda de la complementariedad y perfección a través de la ayuda del hombre para con la mujer y viceversa. El matrimonio surge -insistimos - como algo natural, fruto de una atracción mutua.

La unidad consiste en la imposibilidad de que una persona pueda contraer simultáneamente el vínculo conyugal con diversas personas.

La indisolubilidad implica la imposibilidad jurídica de disolver el vínculo conyugal, lo que debe diferenciarse de la separación, en donde los cónyuges, a pesar de no convivir juntos en virtud de razones legales o fácticas, siguen estando casados. La complementariedad sexual surge entre una pareja de heterosexuales, hombre y mujer, que se complementan en el acto sexual para procrear y dar vida.

\section{Cambios en la ley matrimonial}

Cuando se habla de Derecho Natural, se alude al derecho propio o inherente a la naturaleza humana, que no es creado por un órgano gubernamental, sino que se constituye por criterios y principios rectores de la conducta humana, que los partidarios de esta corriente consideran como eternos e inmutables. El Derecho Positivo debe proteger al Derecho Natural, a los principios y a la naturaleza humana. En el momento en que el Derecho Positivo sobrepasa los límites de la naturaleza, puede causar un gran daño en la humanidad y en la naturaleza, ya que todo comienza a descompensarse. Si la ley matrimonial sufre cambios, la naturaleza también se verá afectada.

En el caso del matrimonio, si la ley no define qué es, existe mayor facilidad para contraer este vínculo lo mismo que para disolverlo. Si se elimina el fin procreativo del matrimonio, existe un opcional a todo lo referente a la finalidad procreativa.

\section{Consecuencias de los cambios en la ley}

Se puede observar cómo durante la Historia, a partir de los años ochenta, la institución matrimonial ha sufrido cambios debidos a la influencia de modificaciones políticas. 
Una de ellas es la terminología empleada en la ley; si se le quita al matrimonio la característica de indisolubilidad y se facilita la opción del divorcio, la consecuencia es que la disolubilidad se convertirá en «propiedad necesaria» de cualquier matrimonio.

Los cambios realizados, conllevan consecuencias sociales a corto, mediano y largo plazo. Entre ellas, han desaparecido antiguos impedimentos como: adulterio, afinidad, orden sacerdotal y voto de castidad. Ahora, el matrimonio no está necesariamente ultimado por la generación y educación de la prole, sino que posee también otros fines que no son -necesariamente- el de la procreación. Esto legitima el que mucha gente prefiera no tener hijos.

Cuando se cambia la edad mínima para contraer matrimonio, la consecuencia es que esta pasa a ser un requisito general para realizar un «contrato», en vez de ser la edad fisiológica y psicológica adecuada para contraer matrimonio.

\section{Uniones de hecho}

Al generalizarse las uniones de hecho, inicia la evasión de la formalización legal del matrimonio, por lo que el Derecho debe atender a la realidad social de estos modos de convivencia sin compromiso. La excepción se torna regla.

El compromiso dota de estabilidad institucional al matrimonio. Sin embargo, el compromiso no existe en las uniones de hecho, a las que se pretende proporcionar similar estabilidad institucional, lo cual es incoherente. Cuando se permiten las uniones de hecho, se pasa de la estabilidad propia de la relación conyugal a la inestabilidad absoluta que caracteriza la unión de hecho.

Para fines del Derecho, las uniones de hecho poseen una figura asimilable al matrimonio; a pesar de ello, el Derecho carece de competencia clara para regular estas figuras, por lo que la unión de hecho se trata de modo diverso según la normativa autonómica que se aplique. 
Cuando no existe compromiso, no existe vínculo jurídico, no existe obligación de vivir juntos, de guardarse fidelidad, y por tanto, no existe tampoco un fundamento para todo el entramado jurídico que luego se desarrolla en la familia. Se debilita el vínculo y se sustituye por el consentimiento continuado.

\section{Del «opcional» procreativo}

El elemento esencial y definitorio de la institución matrimonial es la procreación. La pareja se une en matrimonio con el fin de formar una familia y de dar vida. El amor conyugal es diferente respecto a otros modelos convivenciales, pues posee un carácter de complementariedad sexual orientado a la procreación. Sin la finalidad procreativa, la institución del matrimonio seguramente no existiría, porque si no se contrae matrimonio para formar una institución familiar, entonces no habría razón fundamental alguna para hacerlo.

Cuando se generalizan las uniones de hecho, empieza a radicalizarse el opcional procreativo, en cuanto que, en aras de la no discriminación por causas de orientación sexual, se admiten las uniones homosexuales que, por naturaleza, están absolutamente cerradas a la procreación por la falta de la complementariedad sexual, y con esto, surge una ruptura total. La introducción de las parejas homosexuales en el Derecho de Familia atenta frontalmente, no solo contra la institución matrimonial, sino contra todos los principios del Derecho de Familia.

\section{6. «Matrimonio invertebrado» sin vínculo ni complementariedad sexual}

Cuando se hurtan a la institución matrimonial sus propiedades esenciales, esta institución se vuelve un «matrimonio invertebrado»: sin los elementos y las propiedades esenciales que son la columna vertebral que sostiene y que, en definitiva, convierte al matrimonio en ese paradigma al que todos quieren - deberíanpertenecer. El vínculo jurídico conyugal pierde su consistencia, quedando inmediatamente a merced de la voluntad actual unilateral de uno de los miembros de la pareja. 


\section{Desaparición de la complementariedad sexual y eliminación del vínculo conyugal}

$\mathrm{Si}$ comienza a introducirse el matrimonio entre personas del mismo sexo, el «matrimonio homosexual», se elimina la complementariedad sexual - hasta entonces propiedad esencial del matrimonio-, sustituyéndola por la «relación afectiva de pareja». Cuando se atribuye a un hombre homosexual la posibilidad de ejercitar su derecho a casarse en relación con otra persona de su mismo sexo, se le confiere el derecho a cambiar en sí misma la institución matrimonial, para otorgarle un contenido distinto al que le es propio.

La estructura de un matrimonio entre dos personas del mismo sexo es, en sí misma, naturalmente no procreativa: la distancia entre matrimonio civil y procreación se ha acrecentado notabilísimamente, afectando ahora a la propia estructura de la unión que, al prescindir de la heterosexualidad, prescinde también de la procreación.

La aprobación del divorcio y la facilidad para realizarlo, provoca un espectacular incremento de los divorcios en la sociedad; esto no solo facilita la obtención más accesible y simplificada de la ruptura en cualquier momento, sino que además predispone al divorcio. Una persona puede casarse y divorciarse cuantas veces quiera, debiendo respetar únicamente el plazo de tres meses a partir de cada boda. Con el cambio de la indisolubilidad a la disolubilidad, se olvida que la realidad del divorcio pertenece a una patología del matrimonio, que ahora pasa a ser un proceso normal.

\section{VALORACIÓN CRÍTICA}

El Matrimonio invertebrado, presenta una realidad que no debe pasar desapercibida. No cabe duda que la legislación en torno al matrimonio puede cambiar el rumbo de una sociedad. Estamos ante momentos difíciles donde se legisla a partir de excepciones, donde el matrimonio carece de columna vertebral. El aumento de divorcios no es de extrañarse, debido a la facilidad con la que se disuelve lo indisoluble y se rompe un compromiso probablemente nunca consciente y responsablemente adquirido. Hoy, más que 
nunca, debemos prestar especial atención a la formación de los jóvenes respecto a la trascendencia del matrimonio. Es indispensable replantear si es posible legislar a partir de las patologías, que no construyen a una sociedad sólida y tampoco promueven el desarrollo del pilar más fundamental para la familia funcional. Unidad, indisolubilidad, complementariedad sexual orientada a la procreación, son -y deberán ser- propiedades esenciales e irrenunciables de la institución matrimonial.

Regina Barbero Garralda

María Verónica Roqueñi Healy 